\title{
PENDIDIKAN MULTIKULTURAL PERSPEKTIF AL-QURAN
}

\author{
Tejo Waskito ${ }^{1}$, Miftahur Rohman ${ }^{2}$ \\ ${ }^{1}$ STEBI Lampung \\ ${ }^{2}$ STIT Bustanul Ulum Lampung Tengah \\ e-mail: tejowaskito24@gmail.com
}

\begin{abstract}
Islam has truly taught its followers to respect differences. Basically, human diversity (ethnicity, culture, religion, etc.) is sunnatullah. Long before Orientalists introduced multicultural education, Islam had known it clearly as explained in its Al Qur'an. Multicultural Education is not an attempt to find new syncretism, but rather seeks a meeting point between the differences in background, and makes differences become a blessing for the unity and unity of the people, so as to create an Islamic symphony in the frame of nationalism and pluralism.
\end{abstract}

Keyword: Multicultural Education, Al-Quran Perspective, Diversity, Difference.

\begin{abstract}
Abstrak: Islam sejatinya telah mengajarkan pemeluknya untuk menghargai perbedaan. Pada dasarnya, keragaman (etnis, budaya, agama dan lain-lain) manusia merupakan sunnatullah. Jauh sebelum pemikir orientalis mengenalkan pendidikan multikultural, Islam telah mengenal secara gamblang seperti dijelaskan dalam Al-Qur'an. Pendidikan Multikultural bukanlah upaya untuk mencari sinkretisme baru, melainkan mencari titik temu diantara perbedaan-perbedaan latar belakang itu, dan menjadikan perbedaan menjadi sebuah rahmat bagi persatuan dan kesatuan umat, sehingga tercipta suatu simfoni Islam dalam bingkai nasionalisme dan pluralisme.
\end{abstract}

Kata kunci: Pendidikan Multikultual, Perspektif Al-Quran, Keragaman, Perbedaan. 


\section{PENDAHULUAN}

Seantero umat muslim di dunia sepakat bahwa Al-Quran merupakan kitab Allah yang operasional fungsional sepanjang masa sesuai dengan kondisi sosial geografi dan demografi masyarakat. Namun persoalan yang muncul kemudian adalah kitab Al-Qur'an diturunkan bersifat universal, oleh karena itu, perlu adanya interpretasi teks dan ketika teks dasar ajaran agama (AlQuran) masuk dalam wilayah interpretasi, muncul beragam formula interpretasi, mulai dari interpretasi yang sangat liberal, moderat, hingga yang fundamental dengan berbagai variannya. Dengan demikian, persoalan perbedaan yang paling mendasar bukanlah terdapat pada ajaran agamanya, tetapi pada wilayah interpretasi yang kemudian diturunkan menjadi kerangka operasional sebagai landasan berprilaku.

Salah satu perbedaan interpretasi seperti dimaksudkan di atas adalah perbedaan dalam memahami keragaman etnis, budaya dan agama. Tak jarang sesama umat muslim maupun terhadap non-muslim saling klaim kebenaran dan berujung pada saling mengkafirkan terhadap golongan yang tidak satu bendera, begitu pula sebaliknya. Persoalan agama-khususnya-memang wilayah yang sangat sensitif dalam ranah konstelasi sosial-budaya dan politik. Terlebih mereka yang mempunyai kepentingan tertentu biasanya sangat memanfaatkan sentiment keagamaan demi memuaskan ambisinya. Oleh karena itu, menurut KH. Masdar Farid Masudi, dalam rangka mengatasi persoalan di atas perlu adanya tahap kedewasaan budaya (Abdullah, 2014).

Dalam kondisi semacam ini, hal mendasar yang harus dilakukan adalah membangun perspektif keberagamaan yang lebih mempertimbangkan harmoni-sasi, kemanusiaan dan saling menghargai antar sesama (Naim, 2011). Salah satu kata kunci dalam yang banyak diusung untuk mewujudkan tujuan tersebut adalah pluralisme yang dimanifestasikan melalui pendidikan multikultural. Makalah ini secara spesifik membahas masalah pendidikan multukultural dalam AlQur'an, sehingga dapat di ambil rumusan maslahah: bagaimana konsep pendidikan multikultural dalam perspektif al-qur'an?

\section{PEMBAHASAN}

\section{Pengertian Pendidikan Multikultural}

Dalam kehidupan manusia, pendidikan diartikan sebagai upaya mengembangkan kreativitas dan produktivitas berpikir peserta didik dalam menginternalisasikan nilai-nilai moralitas, baik nilai-nilai insani maupun nilai-nilai Ilahi yang dianut oleh masyarakat melalui proses pembelajaran. Istilah pendidikan dalam KBBI berarti proses pengubahan sikap dan tata laku seseorang atau kelompok orang dalam usaha mendewasakan manusia melalui upaya pengajaran dan pelatihan (Nasional, 2008). 
Ki Hajar Dewantoro memberikan definisi pendidikan sebagai daya upaya untuk memajukan perkembangan budi pekerti (kekuatan batin), kekuatan pikiran (intelektual) dan jasmani anak-anak. Maksudnya adalah agar kita dapat memajukan kesempurnaan hidup, yaitu kehidupan dan penghidupan anak-anak, selaras dengan alamnya dan masyarakatnya (Ekosusilo \& Kasihadi, 1993). Sedangkan pendidikan menurut KH. Hasyim Asy'ari adalah upaya memanusiakan manusia secara utuh (insan kamil), sehingga manusia dapat bertaqwa (takut) kepada Allah swt dengan sebenar-benarnya mengamalkan segala perintah-Nya, mampu menegakkan keadilan di muka bumi, beramal shalih dan maslahat. Sehingga pantas menyandang predikat makhluk yang paling mulia dan lebih tinggi derajatnya dari segala jenis makhluk Allah yang lainnya (Noor, 2010).

Lebih lanjut menurut UU Sisdiknas (UU RI No 20 Tahun 2003) BAB I Pasal I dijelaskan bahwa "pendidikan adalah usaha sadar dan terencana untuk mewujudkan suasana belajar dan proses pembelajaran agar peserta didik secara aktif mengembangkan potensi dirinya untuk memiliki kekuatan sepiritual keagamaan, pengendalian diri, kepribadian, kecerdasan, akhlak mulia, serta keterampilan yang diperlukan dirinya, masyarakat, bangsa dan negara (Sisdiknas, 2003).

Sedangkan istilah "multikultural" ditinjau dari aspek kebahasaan mengandung dua pengertian yang sangat kompleks yaitu: "multi" yang berarti keragaman, dan "kultural" yang berarti budaya. Istilah tersebut mempunyai implikasi yang sangat luas dan kompleks karena berhubungan dengan ideologi, politik dan ekonomi (Sulalah, 2015). Oleh sebab itu, multikultural berkaitan pula dengan prinsip-prinsip demokrasi, hak dan kebebasan hidup kelompok-kelompok masyarakat yang ada di suatu komunitas, karena mereka memiliki budaya masing-masing (Rohman \& Lessy, 2017). Kemudian Conrad P. Kottak memberikan penjelasan bahwa kultur mempunyai karakter-karakter khusus, yaitu: 1) sebagai muatan; 2) sebagai fungsi; 3) sebagai indikator; 4) sebagai tujuan; 5) sebagai aktifitas; 6) sebagai model; 7) sebagai proses. Sementara Purwasito mengatakan bahwa kultur adalah hasil penciptaan, perasaan dan prakarsa manusia berupa karya yang bersifat fisik dan non-fisik (Kottak, 1987).

Dengan demikian, dapat dipahami bahwa pengertian pendidikan multikultural adalah proses pengembangan seluruh potensi manusia yang menghargai pluralitas dan heterogenitas sebagai konsekuensi keragaman budaya, etnis, suku dan aliran (agama). Pendidikan multikultural juga dapat diposisikan sebagai bagian dari upaya komprehensif dalam mencegah dan menanggulangi konflik etnis, konflik agama, radikalisme agama, separatisme, dan disintegrasi bangsa dan negara (Andrik, 2003). Menurut Purwasito, pada umumnya ada tiga hal yang melatar belakangi disinteraksi antara kelompok mayoritas dan orang-orang yang termasuk golongan minoritas yaitu: Pertama: prasangka historis; Kedua: diskriminasi; dan Ketiga: prasangka 
superioritas in-group feeling yang berlebihan dengan menganggap inferior pihak lain (out-group). Ketika ketiga hal di atas disinyalir menjadi akar disintegrasi, maka sangat memungkinkan berimplikasi terhadap runtuhnya sebuah bangsa (Andrik, 2003). Oleh karena itu, melalui pendidikan multikultural diharapkan muncul kekenyalan dan kelenturan mental bangsa dalam menghadapi benturan konflik sosial, sehingga persatuan bangsa tidak mudah terpecah belah.

Dawam \& Alafsana (2003) mengatakan bahwa terdapat beberapa pointer (tujuh) yang menjadi orientasi bagi pendidikan multikultural, yaitu: Pertama: orientasi ke-manusiaan (Humanisme), yakni nilai kemanusiaan bersifat universal dan global, di atas semua suku, ras, golongan dan agama. Kedua: orientasi kebersamaan, yakni kebersamaan dibangun dengan tidak merugikan dirinya sendiri, orang lain, lingkungan dan negara. Dalam arti kebersamaan bukan yang bersifat kolektif-koruptif, tetapi dengan kebersamaan ini diharapkan akan muncul manusia yang aktif, kreatif, toleran tanpa bidden agenda, kebersamaan tanpa unsur kolutif, terbuka tanpa manipulatif, dan kreatif tanpa unsur dominatif.

Ketiga: orientasi kesejahteraan (welvarisme), maksudnya bukan terjebak pada pemenuhan materi yang berlebih dan sama banyaknya oleh semua orang, tetapi masyarakat yang secara sadar tidak dipaksa mengatakan bahwa mereka telah sejahtera. Keempat: orientasi kedamaian (peacevisme), kedamaian tercipta apabila kebutuhan dasarnya terpenuhi, meresa aman, dihargai, diakui, dan diperlakukan sama oleh semua manusia yang berinteraksi dengannya. Kelima: orientasi proporsional, yakni sebuah nilai yang dari segi apapun dipandang sangat tepat. Keenam: orientasi mengakui pluralitas dan heterogenitas. Ketujuh: orientasi anti hegemoni dan anti dominasi, yakni tidak hanya dibidang politik, tetapi sudah masuk pada bidang pelayanan masyarakat.

\section{Pendidikan Multikultural Perspektif Al-Qur'an}

Banyak dalil-dalil dalam Al-Qur'an yang membahas tentang pendidikan multikultural, seperti bahasan berikut ini.

1. Q.S. Al-Hujuraat (49) : 13.

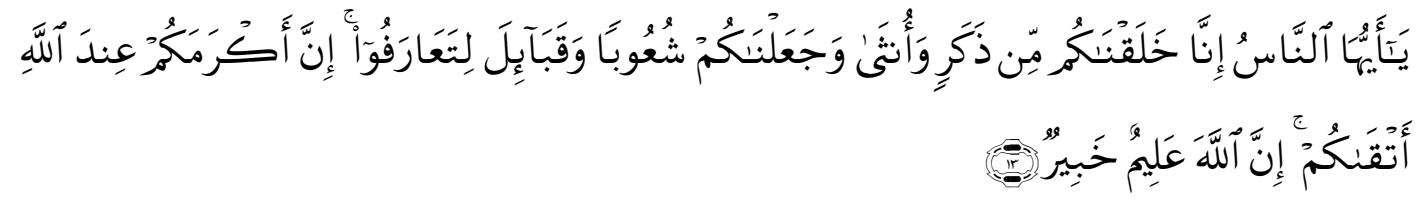

Artinya: Hai manusia, Sesungguhnya Kami telah menciptakan kamu dari seorang laki-laki dan seorang perempuan dan menjadikan kamu berbangsa - bangsa dan bersukusuku supaya kamu saling mengenal. Sesungguhnya orang yang paling mulia diantara kamu disisi Allah ialah orang yang paling taqwa diantara kamu. 
Sesungguhnya Allah Maha mengetahui lagi Maha Mengenal. (Q.S. Al-Hujuraat: 13).

Asbab Al-Nuzul ayat tersebut adalah diriwayatkan dari Abu Mulaikah dia berkata, "pada peristiwa pembebasan kota Makkah (Fathu Makkah), Bilal naik ke atas Ka'bah lalu mengumandangkan adzan. Melihat hal itu, berkatalah 'Attab bin Said bin Abil 'Ish, "Segala puji bagi Allah yang telah mencabut nyawa ayahku, sehingga tiada menyaksikan hari ini." Sedang Al-Haris bin Hisyam berkata, "Muhammad tidak menemukan selain burung gagak yang hitam ini untuk dijadikan mu'adzin." dan Suhail bin Amr berkata, "Jika Allah menghendaki sesuatu maka bisa jadi Dia merunahnya." Maka datanglah Malaikat Jibril kepada nabi Muhammad saw. memberitahukan terkait dengan apa yang mereka katakana (Mustofa, 1992).

Ibnu "Asakir juga meriwayatkan dalam kitab "al-Mubhamaat" terkait dengan asbabun nuzul ayat di atas, "saya menemukan tulisan tangan dari Ibnu Basyikual yang menyebutkan bahwa Abu Bakar bin Abu Daud meriwayatkan dalam kitab tafsirnya, "ayat ini turun berkenaan dengan Abi Hindun. Suatu ketika, Rasulullah saw. menyuruh bani Bayadhah untuk menikahkan Abu Hindun dengan wanita dari suku mereka. akan tetapi, mereka berkata, "wahai Rasulullah, bagaimana mungkin kami akan menikahkan anak wanita kami dengan seorang budak? Sebagai responnya, turunlah ayat tersebut" (As-Suyuthi, 2008).

Penjelasan ayat: Pesan utama yang terkandung dalam ayat di atas adalah keragaman jenis kelamin, individu, suku dan bangsa adalah untuk saling mengenal. Sikap yang ditimbulkan oleh komitmen untuk saling mengenal tersebut merupakan sikap positif konstruktif yang bersifat aktif (Munawar \& Husin, 2005). Dengan mengenal diri pada orang lain pada komitmen di atas, maka terjalinlah saling pengertian akan prilaku, keinginan, kelebihan dan kekurangan masing-masing individu, suku atau bangsa. At-Thabari mengatakan, Rasulullah saw. berkhutbah di Mina di tengah hari-hari tasyriq, sedang beliau berada di atas untanya. Beliau berkata, "Hai manusia, ketahuilah sesungguhnya Tuhanmu adalah Esa dan ayahmu satu. Ketahuilah, tidak ada kelebihan bagi orang Arab atas seorang 'Ajam (bukan Arab) maupun orang 'Ajam atas orang Arab, atau bagi orang hitam atas orang merah, atau bagi orang merah atas orang hitam, kecuali dengan takwa (Mustofa, 1992). Diriwayatkan pula dari Abu Malik Al-Asy'ari, ia berkata bahwa Rasulullah saw. bersabda: "sesungguhnya Allah tidak memandang kepada pangkat-pangkat kalian dan tidak pula kepada nasab-nasabmu dan tidak pula kepada tubuhmu, dan tidak pula kepada hartamu, akan tetapi memandang kepada hatimu. Maka barang siapa memiliki hati yang shalih, maka Allah belas kasih kepadanya. Kalian tiada lain adalah anak cucu Adam dan yang paling dicintai Allah diantara kalian adalah yang paling bertakwa diantara kalian (Mustofa, 1992). 
Dalam tafsir al-Misbah dijelaskan bahwa, sesungguhnya Kami (Allah swt) menciptakan manusia dari seorang laki-laki dan seorang perempuan adalah pengantar untuk menegaskan bahwa semua derajat kemanusiaannya sama disisi Allah swt. Tidak ada perbedaan antara satu golongan dengan golongan yang lain. Tidak ada perbedaan pada nilai kemanusiaan antara lakilaki dan perempuan, karena semua manusia diciptakan dari seorang laki-laki dan perempuan. Allah juga menjadikan manusia dengan bersuku-suku, berbangsa-bangsa dan berkelompokkelompok. Semua mendapat perlakuan yang sama oleh Allah swt. Tujuannya hanya satu, yaitu "li ta'arafü" (saling mengenal satu sama lain secara baik). Pengantar tersebut mengantar pada kesimpulan bahwa "sesungguhnya yang paling mulia diantara kamu disisi Allah swt. adalah yang paling bertaqwa”. Dengan demikian, hal yang membedakan manusia satu dengan yang lain bukan terletak pada sukunya, rasis ataupun bahasanya, tetapi lebih kepada tingkat ketaqwaannya kepada Allah swt. Karena itu, berusahalah untuk meningkatkan ketaqwaan agar menjadi yang termulia disisi Allah swt (Shihab, 2006).

Jika keragaman individu, suku, bangsa dan agama dianalogikan dengan tinjauan perspektif struktural fungsional, misalnya dianalogikan dengan kemajemukan anggota tubuh pada diri seorang manusia. Manusia memiliki kepala, badan, tangan dan kaki yang keseluruhannya berbeda satu sama lain, namun tetap bersatu dalam satu kesatuan wujud manusia (Munawar \& Husin, 2005). Masing-masing anggota tubuh memiliki fungsi yang unik. Masing-masing berfungsi sesuai dengan proporsionalitasnya sehingga anggota yang satu meski sedemikian vital fungsinya tidak akan dapat menggantikan organ lainnya.

Jika dikaitkan dengan masyarakat yang heterogen, setiap masyarakat memiliki fungsifungsi tertentu dalam hubungan sosial, baik itu pada skala kecil seperti hubungan antar keluarga dengan keluarga, maupun skala besar seperti hubungan kelompok dalam masyarakat dalam negara. Dengan kata lain, keragaman etnis, budaya, dan agama memiliki tempat tersendiri dalam membangun kebersamaan untuk eksistensi bersama. Masing-masing individu memiliki peranan yang penting dalam mewujudkan kebersamaan (Munawar \& Husin, 2005). Oleh karena itu, seyogyanya setiap individu maupun kelompok memiliki rasa tanggung jawab terhadap kelestarian, ketenteraman, dan kesejahteraan dalam mewujudkan eksistensi kebersamaan tanpa adanya hegemoni kekuasaan terhadap kelompok minoritas atau sebaliknya.

2. Q.S. Ar-Ruum (30) : 22

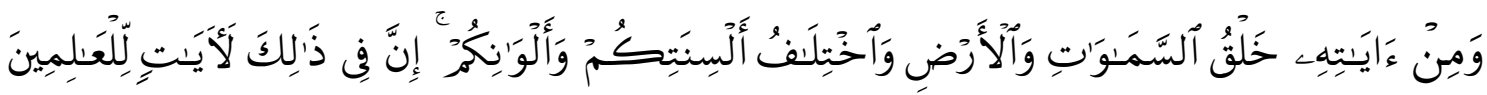


Artinya: Dan di antara tanda-tanda kekuasaan-Nya ialah menciptakan langit dan bumi dan berlain-lainan bahasamu dan warna kulitmu. Sesungguhnya pada yang demikan itu benar-benar terdapat tanda-tanda bagi orang-orang yang mengetahui. (Q.S. ArRuum/30:22).

Dalam Q.S. Ar-Ruum: 22, M. Quraish Shihab menjelaskan, di bumipun terdapat sekian banyak tanda-tanda kekuasaan Allah swt. Disini yang disinggung adalah yang terdapat dalam diri manusia sekaligus dengan peredaran matahari dan bumi. Lebih lanjut Quraish Shihab mengatakan bahwa yang disebutkan ialah perbedaan lidah, ini karena terjadi perbedaan tempat tinggal di bumi. Demikian juga warna kulit, antara lain dipengaruhi oleh sinar matahari. Ayat tersebut menekankan tentang perbedaan, karena perbedaan itu lebih menonjolkan kuasa-Nya. Betapa tidak, manusia berbeda-beda dalam segala aspek, padahal manusia lahir dari sumber yang sama. Kata alsinatikum adalah jamak dari lisan yang berarti lidah. Ia juga digunakan dalam arti lidah dan suara. Penelitian terakhir menunjukkan bahwa tidak seorangpun yang memiliki suara yang sepenuhnya sama dengan orang lain. Persis seperti sidik jari (Shihab, 2006).

3. Q.S. Yunus (10) : 99

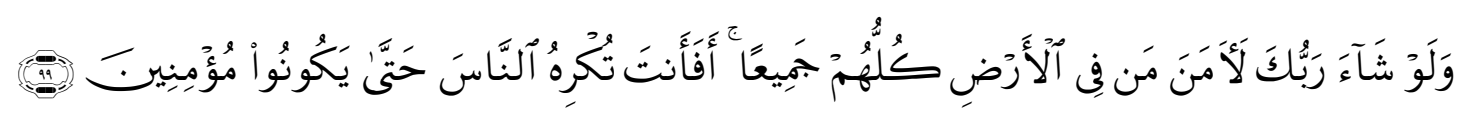

Artinya: "Dan Jikalau Tuhanmu menghendaki, tentulah beriman semua orang yang di muka bumi seluruhnya. Maka Apakah kamu (hendak) memaksa manusia supaya mereka menjadi orang-orang yang beriman semuanya?” (Q.S. Yunus/10 : 99).

Ayat di atas menjelaskan bahwa, perbedaan menjadi hal yang niscaya bagi Allah swt. Adanya perbedaan merupakan sunnatullah sekaligus menjadi kebesaran dan kekuasaan Allah akan ciptaannya. Inilah yang membedakan antara keterbatasan kekuasaan manusia dengan kekuasaan Allah. dari hal-hal yang sangat kecilpun diantara semua makhluk-Nya di seantero dunia ini, tidaklah ada kesamaan antara satu dengan lainnya. Dengan tegas Allah swt mengatakan bahwa "Jikalau Tuhanmu menghendaki, tentulah beriman semua orang yang di muka bumi seluruhnya. Maka Apakah kamu (hendak) memaksa manusia supaya mereka menjadi orang-orang yang beriman semuanya?” ini menjadi bukti yang nyata bahwa perbedaan merupakan suatu keniscayaan bagi Allah swt. Dalam pengertian ayat tersebut, terdapat pula dalam firman Allah yang lain yang menjelaskan hal serupa, yakni dalam Q.S. Al-An'am (7) ayat 107 yang artinya: "Dan kalau Allah menghendaki, niscaya mereka tidak mempersekutukan(Nya). dan Kami tidak menjadikan kamu pemelihara bagi mereka; dan kamu sekali-kali bukanlah pemelihara bagi mereka. dan Q.S. Huud (11) ayat 118 yang artinya: Jikalau Tuhanmu menghendaki, tentu Dia menjadikan manusia umat yang satu, tetapi mereka Senantiasa berselisih pendapat. Maka apakah kita (manusia) hendak memaksa manusia menjadi 
orang-orang yang beriman semua? Sesungguhnya itu semua tidak akan mampu untuk dilakukan, karena itu akan mengingkari pluralitas dan heterogenitas yang sudah menjadi ketentuan dan ketetapan Allah swt.

Pemaksaan akan hal memeluk islam agama juga bukan termasuk risalah nabi Muhammad saw, karena sesungguhnya nabi Muhammad saw hanyalah menyampaikan tanggung jawab kerasulan, bukan sebagai pemaksaan. Ini sesuai dengan firman Allah dalam Q.S. Asy-Syuura (42) ayat 48 yang artinya: "Jika mereka berpaling Maka Kami tidak mengutus kamu sebagai Pengawas bagi mereka. kewajibanmu tidak lain hanyalah menyampaikan (risalah). Sesungguhnya apabila Kami merasakan kepada manusia sesuatu rahmat dari Kami Dia bergembira ria karena rahmat itu. dan jika mereka ditimpa kesusahan disebabkan perbuatan tangan mereka sendiri (niscaya mereka ingkar) karena Sesungguhnya manusia itu Amat ingkar (kepada nikmat).” Kemudian dalam Q.S. Qaaf (50) ayat 45 dijelaskan bahwa "Kami lebih mengetahui tentang apa yang mereka katakan, dan kamu sekali- kali bukanlah seorang pemaksa terhadap mereka. Maka beri peringatanlah dengan Al Quran orang yang takut dengan ancaman-Ku." Serta dalam Q.S. al-Baqarah (2) ayat 256 secara tegas Allah swt mengatakan "Tidak ada paksaan untuk (memasuki) agama (Islam); Sesungguhnya telah jelas jalan yang benar daripada jalan yang sesat. karena itu Barangsiapa yang ingkar kepada Thaghut dan beriman kepada Allah, Maka Sesungguhnya ia telah berpegang kepada buhul tali yang Amat kuat yang tidak akan putus dan Allah Maha mendengar lagi Maha mengetahui."

4. Q.S. Al-Mumtahanah (60): 8.

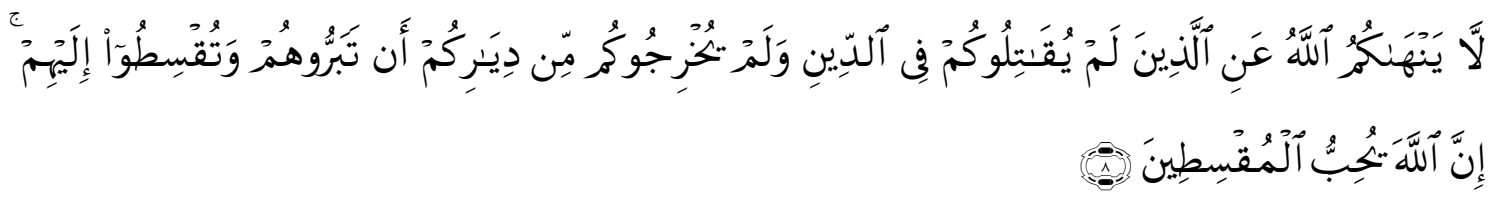

Artinya: "Allah tidak melarang kamu untuk berbuat baik dan Berlaku adil terhadap orangorang yang tiada memerangimu karena agama dan tidak (pula) mengusir kamu dari negerimu. Sesungguhnya Allah menyukai orang-orang yang Berlaku adil’. (Q.S. Al-Mumtahanah/60:8).

Asbabun Nuzul Ayat: Para mufassir berbeda pendapat tentang siapa yang dimaksud dengan orang kafir yang tiada memerangi orang muslin yang disebutkan dalam Q.S. AlMumtahanah/60 : 8. Sebagainmana diterangkan oleh H.R. Bukhari yang dikutip oleh Ahmad Hatta dijelaskan sebagai berikut: Asma' binti Abu Bakar r.a. berkata, “ayat ini diturunkan berkenaan denganku yang suatu ketika mendapat kunjungan dari ibu kandungku, Raghibah (yang masih kafir). Kemudian aku bertanya kepada Rasulullah saw, "wahai Rasulullah, 
bolehkah aku menyambung tali silaturrahim dengannya?", Rasulullah saw menjawab "Ya"(Mustofa, 1992).

Al-Maraghi menceritakan sebab turunnya ayat sebagai berikut: telah diriwayatkan oleh Ahmad yang berasal dari Abdullah bin Zubair, bahwa pada suatu ketika Qutaibah binti Abd alUzziy telah menjumpai anaknya yang bernama Asma binti Abi Bakar sambil membawa hadiah yang bernama al-sinab, aqith dan samin, dalam keadaan ia musyrik. Pada mulanya Asma menolak hadiah tersebut dan melarangnya masuk ke rumah hingga ia terlebih dahulu meminta pendapat Aisyah mengenai masalah tersebut. Setealah itu turunlah ayat ke-9 yang lebih menjelaskan maksud ayat di atas (Maraghi, 2001). Kemudian Al-Qurtubi menceritakan dari banyak ahli takwil yang berpendapat, ayat ini tetap muhkamat dan boleh berlaku baik kepada orang-orang musyrik selama mereka tidak menunjukkan sikap permusuhan, meskipun telah putus hubungan dengan mereka. kemudian turun ayat ke-9 yang menjelaskan kafir sematamata tidaklah memutuskan persahabatan antara orang islam dengan orang kafir. Adapun yang memutuskan persahabatan diantara mereka adalah orang kafir yang memusuhi islam dan membantu musuh-musuh islam dalam menghalangi dakwah sebagaimana telah diterangkan pada tafsir yang lain (Maraghi, 2001).

Penjelasan Ayat: Ayat tersebut ditafsirkan oleh Al-Maraghi yang mengatakan, "semoga Allah menjadikan rasa cinta antara kamu dengan orang-orang kafir Makkah setelah setelah mereka sebelumnya saling bermusuh-musuhan, serta terjalin ikatan yang kuat setelah mereka bercerai-berai." Menurut hemat penulis, secara ayat di atas sangat menekankan anjuran berlaku adil, keadilan dalam arti yang sangat luas, yakni keadilan dalam bidang politik, agama, hukum dan hak asasi manusia. Misalnya seorang pemimpin berlaku adil kepada rakyatnya, baik perorangan maupun kelompok. Terlepas dari itu, keadilan tidaklah memandang latar belakang dari individu ataupun golongan tertentu dalam hal suku, rasisme, budaya, dan agama. Tidak ada saling hegemoni antara kelompok mayoritas terhadap kelompok minoritas. Mendapatkan keadilan adalah hak semua individu dalam sebuah negara, bahkan dalam hal peperangan dan permusuhanpun Allah sangat menganjurkan hambanya untuk berlaku adil dan penuh kasih sayang terhadap musuhnya, karena diantara orang-orang yang bermusuhan itu terdapat rasa kemanusiaan, keadilan dan ketuhanan. Hal ini dijelaskan oleh Allah dalam ayat sebelumnya Q.S. al-Mumtahanah (60) ayat 7 yang artinya: Mudah-mudahan Allah menimbulkan kasih sayang antaramu dengan orang-orang yang kamu musuhi di antara mereka. dan Allah adalah Maha Kuasa. dan Allah Maha Pengampun lagi Maha Penyayang.

Dari beberapa penjelasan ayat-ayat di atas, menurut hemat penulis, terdapat beberapa maksud yang terkandung kandungan ayat-ayat di atas, diantaranya adalah perbedaan warna 
kulit, bahasa, ras, dan agama dipandang sebagai tanda kekuasaan dan kasih sayang Allah (Q.S. al-Hujuraat/49:13) dan (Q.S. ar-Ruum/30:22), ini menjadi bukti bahwa adanya perbedaan merupakan sebuah keniscayaan yang sengaja diciptakan oleh Allah swt sebagai bukti atas kebesaran kekuasaan-Nya, karena jika Allah menghendaki maka sangat memungkinkan umat manusia menjadi umat yang satu (Q.S. Yunus/10:99). Oleh karena itu, seharusnya perbedaan menciptakan kedekatan antar sesama, bukan menciptakan diskriminasi saling menghegemoni dan memonopoli.

Berdasarkan hal tersebut, konsep pluralitas dan heterogenitas bahasa, budaya, ras, dan agama sudah menjadi bagian urgen yang tak terpisahkan dari agama islam. Al-Qur'an juga sangat menghormati menghargai terhadap kaum non-muslim dan menganjurkan untuk hidup bersama, hal ini sesuai ayat AlQur'an yang menetapkan prinsip "tidak ada paksaan dalam beragama” (Q.S. al-Baqarah/2:256), "bagiku agamaku, bagimu agamamu” (Q.S. al-Kafirun/ 109:6), dan "bagiku amal perbuatanmu, bagimu amal perbuatanmu" (Q.S. Yunus/10:41) tanpa ada hegemoni dan intimidasi.

Secara historis, perjumpaan islam dengan agama lain telah berlangsung sejak zaman nabi Muhammad saw Islam datang dalam konteks agama Yahudi dan Nasrani. Oleh karena itu, dalam membentuk sebuah tatanan masyarakat baru di Madinah, Nabi tidak menafikan kelompok-kelompok di luar Islam, melainkan mengakomodir kepentingan mereka dan mengajak untuk bekerjasama. Dalam sejarah, langkah ini yang kemudian dikenal dengan "Piagam Madinah". Prinsip kebebasan yang dideklarasikan oleh nabi diantaranya adalah: prinsip egalitarianisme, prinsip keadilan dan permusyawaratan, kebersamaan secara kooperatif dan solidaritas, semangat persaudaraan dan anti kekerasan (Achmad, 2001).

Lebih lanjut Al-Qur'an juga tidak menjustifikasi Ahli Kitab sebagai agama yang tidak dapat diterima, dalam Q.S. Ali-imran (3) : 113-115 Allah menjelaskan "Mereka itu tidak sama; di antara ahli kitab itu ada golongan yang Berlaku lurus, mereka membaca ayat-ayat Allah pada beberapa waktu di malam hari, sedang mereka juga bersujud (sembahyang). Mereka beriman kepada Allah dan hari penghabisan, mereka menyuruh kepada yang ma'ruf, dan mencegah dari yang Munkar dan bersegera kepada (mengerjakan) pelbagai kebajikan; mereka itu Termasuk orang-orang yang saleh. Dan apa saja kebajikan yang mereka kerjakan, Maka sekali-kali mereka tidak dihalangi (menerima pahala) nya; dan Allah Maha mengetahui orang-orang yang bertakwa."

Demikian juga Al-Qur'an tiada mencap mereka sebagai orang yang tidak jujur, seperti dijelaskan dalam Q.S. Ali-Imran (3) : 75) sebagai berikut: "Diantara ahli kitab ada orang yang jika kamu mempercayakan kepadanya harta yang banyak, dikembalikannya kepadamu; dan di 
antara mereka ada orang yang jika kamu mempercayakan kepadanya satu dinar, tidak dikembalikannya kepadamu kecuali jika kamu selalu menagihnya." Bahkan terhadap Ahli Kitab (Yahudi dan Nasrani) Islam islam mempunyai sikap yang istimewa, yakni diperbolehkannya memakan makanan mereka yang halal menurut islam dan mengawini perempuan-perempuan dari mereka. seperti dijelaskan dalam Q.S. al-Maidah (5) : 5. yang artinya: "Pada hari ini Dihalalkan bagimu yang baik-baik. makanan (sembelihan) orang-orang yang diberi Al kitab itu halal bagimu, dan makanan kamu halal (pula) bagi mereka. (dan Dihalalkan mangawini) wanita yang menjaga kehormatan diantara wanita-wanita yang beriman dan wanita-wanita yang menjaga kehormatan di antara orang-orang yang diberi Al-kitab sebelum kamu, bila kamu telah membayar mas kawin mereka dengan maksud menikahinya, tidak dengan maksud berzina dan tidak (pula) menjadikannya gundik-gundik. Barangsiapa yang kafir sesudah beriman (tidak menerima hukum-hukum Islam) Maka hapuslah amalannya dan ia di hari kiamat Termasuk orang-orang merugi.

Suatu hal terpenting dalam kaitannya dengan pluralitas agama adalah Allah berfirman dalam Q.S. Al-Mumtahanah (60) : 8-9, seperti yang telah dijelaskan di atas, yaitu sebagai berikut: "Allah tidak melarang kamu untuk berbuat baik dan Berlaku adil terhadap orangorang yang tiada memerangimu karena agama dan tidak (pula) mengusir kamu dari negerimu. Sesungguhnya Allah menyukai orang-orang yang Berlaku adil. Sesungguhnya Allah hanya melarang kamu menjadikan sebagai kawanmu orang-orang yang memerangimu karena agama dan mengusir kamu dari negerimu, dan membantu (orang lain) untuk mengusirmu. dan Barangsiapa menjadikan mereka sebagai kawan, Maka mereka Itulah orang-orang yang zalim.” Jamal al-Banna mengatakan bahwa penerimaan Al-Qur'an terhadap pluralitas agama didasarkan pada dua alasan, yakni alasan historis dan objektif. Secara historis tidak dapat dipungkiri bahwa lahirnya tiga agama besar (Islam, Kristen, Yahudi) berasal dari satu bapak, yakni Ibrahim a.s. sedangkan alasan objektifnya lebih didasarkan pada cara pandang islam sendiri terhadap konsep "Tuhan sebagai pencipta dan pengatur pergerakan alam raya", termasuk mengatur sistem pergerakan sejarah manusia. Dia-lah yang menurunkan semua agama sejak nabi Adam a.s hingga nabi Muhammad saw, dan masing-masing agama tidak perlu dipertentangkan (Maraghi, 2001).

Dengan demikian, dapat digeneralisasikan bahwa nilai-nilai pendidikan multikultural yang terkandung dalam Al-Qur'an adalah sebagai berikut: pertama: kewajiban bersikap toleran terhadap pluralitas dan heterogenitas (Q.S. 2:256, Q.S. 49:13, Q.S. 30:22); kedua: perintah menegakkan kebenaran keadilan (Q.S. 5:8); ketiga: prioritas kebaikan (Q.S. 5:48) dan menjadi 
sesorang yang pemaaf (Q.S. 7:199) serta perintah amar ma'ruf nahi munkar (Q.S. 2:195) dan lain-lain.

\section{Pendidikan Multikultural (Tinjauan Theologis, Filosofis dan Sosiologis)}

Secara theologis, keragaman dapat diyakini sebagai sunnatullah. Artinya adanya pluralitas merupakan suatu keniscayaan yang bersifat natural yang telah ditetapkan dan digariskan oleh Allah swt. untuk senantiasa berlaku dalam perputaran cosmos. Ketika pluralitas dipahami sebagai sunnatullah maka pengingkaran terhadap pluralitas berarti kekufuran terhadap sunnatullah. Terungkap dalam ayat di atas baik secara eksplisit maupun implisit bahwa adanya pengakuan Allah terhadap fakta pluralitas yang teraktualisasi dalam diri manusia dan menjadi keniscayaan mutlak tidak mungkin dibantah oleh siapapun (Munawar \& Husin, 2005). Dengan kata lain, manusia diakui sebagai individu yang unik, parsial, plural dan sekaligus sebagai ayat Allah yang maha kuasa. Dengan demikian pluralitas dapat dipahami sebagai rahmatan lil-áamin. Di samping itu, dalam kaitannya dengan hubungan antar umat beragama, islam bukanlah sebuah agama yang eksklusif ataupun baru, islam merupakan bagian dari keseluruhan sejarah perjalanan agama. Terbukti dengan kitab suci Al-Qur'an yang melanjutkan dan membenarkan kitab-kitab sebelumnya (Lihat. Q.S. Yusuf/12 : 111) dan Nabi Muhammad saw pun hanyalah salah satu dari mata rantai kenabian sebelumnya yang wajib diimani oleh kaum muslimin.

Secara filosofis, multikultur dibangun atas prinsip pluralisme, yaitu sikap, pemahaman dan kesadaran terhadap kenyataan adanya kemajemukan, keragaman sebagai sebuah keniscayaan, sekaligus ikut berperan aktif memberikan makna signifikansinya dalam konteks pembinaan dan perwujudan kehidupan berbangsa dan bernegara kearah yang manusiawi dan bermartabat (Rohman, 2018). Pluralitas adalah keragaman dalam sebuah wujud persatuan. Eksistensi manusia dengan keragaman dimensi yang dimilikinya merupakan sebuah system yang inheren dan padu, bukan terpisah-pisah yang berakibat terjadinya dikotomisasi atau paradoksal (Rohman, 2016).

Lebih lanjut istilah kenal-mengenal tidaklah dipahami hanya sebatas literalis, namun lebih kepada saling memahami karakter, budaya, sikap, tingkah laku, antar sesama manusia (Rohman \& Mukhibat, 2017). Hal ini tentunya menolak fanatisme rasial, fanatisme budaya, dan fanatisme agama terhadap manusia yang lain. Lebih jauh, hal ini berarti mengingkari tindakan egois personal dan egois sosial yang mengklaim dan memonopoli kebenaran kelompok sendiri. Dengan saling mengenal maka lahirlah dinamisasi masyarakat yang saling mengisi kekurangan antara sesama, bukan saling menghancurkan dan membinasakan (Munawar \& Husin, 2005).

Sedangkan secara sosiologis, pluralitas individu maupun masyarakat yang ditandai dengan adanya perbedaan ras, klasifikasi sosial seperti budaya dan agama, stratifikasi sosial seperti kelas 
atas, kelas menengah dan kelas bawah adalah bagian dari satu keniscayaan system masyarakat (Munawar \& Husin, 2005). Hal ini dipandang sebagai bagian utuh yang memberi warna dan nuansa dinamis dalam masyarakat itu sendiri, baik masyarakat dalam lingkup sederhana maupun lingkup yang kompleks. Manusia tanpa pluralitas kelas, kerja, pendapatan, tentunya akan menjadikan dunia ini sebagai buana yang vakum tanpa dinamisasi. Karena dinamisasi merupakan suatu kemestian yang dibutuhkan makhluk bumi untuk mencapai taraf kehidupan yang diidealisasikan, yaitu peradaban yang dapat memakmurkan dan menyejahterakannya lahir dan batin. Implikasi yang ditemukan selanjutnya adalah budaya keterbukaan, saling menghargai dan memahami.

\section{Etika Pendidikan Multikultur Perspektif Al-Qu'an}

Merujuk pada kedua ayat di atas, ada beberapa pointer yang menjadi prinsip etika dalam hubungan sosial antar umat beragama, yaitu: pertama: prinsip egalitarianisme (al-musawat) yang memandang manusia ditakdirkan sama derajatnya; kedua: prinsip keadilan (al-adalab) yang merupakan implikasi dari bertaqwa dalam arti tidak diskrimitatif, baik dalam pengelolaan sumber daya ekonomi, politik, sosial budaya, pendidikan maupun penerapan hukum; ketiga: prinsip toleransi (tasamuh) dan kompetisi dalam kebaikan (fastabiq al-khairat) sesuai dengan UUD 1945 Pasal 29 ayat 2; keempat: prinsip saling menghormati, bekerjasama, dan pertemanan. Prinsip ini merupakan implikasi sosiologis dari ketiga poin sebalumnya. Prinsip ini sangat ditekankan dalam al-Qur'an karena dipandang sama dengan menghormati agama sendiri; kelima: prinsip koeksistensi damai (al-ta'ayusy al-silmi). Prinsip ini merupakan dasar hubungan antar manusia sesuai dengan arti genetik islam itu sendiri, yaitu perdamaian; keenam: dialog yang arif-konstruktiftransformatif (mujadalat bi al-hasan) (Naim, 2011).

\section{PENUTUP}

Berdasarkan hasil yang dapat penulis paparkan dapat disimpulkan bahwa pendidikan multikultural merupakan proses pengembangan seluruh potensi manusia yang menghargai pluralitas dan heterogenitas sebagai upaya komprehensif dalam mencegah dan menanggulangi konflik etnis, konflik agama, radikalisme agama, separatisme, dan disintegrasi bangsa.

Pada dasarnya, keragaman (etnis, budaya, agama dan lain-lain) manusia merupakan sunnatullah. Jauh sebelum pemikir orientalis mengenalkan pendidikan multikultural, Islam telah mengenal secara gamblang seperti dijelaskan dalam kitab sucinya (Al-Qur'an). Pendidikan Multikultural bukanlah upaya untuk mencari sinkretisme baru, melainkan mencari titik temu diantara perbedaan-perbedaan latar belakang itu, dan menjadikan perbedaan menjadi sebuah 
rahmat bagi persatuan dan kesatuan umat, sehingga tercipta suatu simfoni Islam dalam bingkai nasionalisme dan pluralisme.

Meminjam filosofi dari bambu yang hidup dalam rumpun, meskipun saling gesekan antar sesama pohon, namun mereka tidak saling melukai, justru saling menguatkan ketika dilanda badai. Serta jadilah seperti pelangi, meski memiliki latar belakang warna yang berbeda, namun ketika warna tersebut disatu padukan, diantara warna tersebut tidak saling menghegemoni dan mendominasi, justru saling berkontribusi sehingga nampak lebih indah perbedaan warna tersebut jika diamati.

\section{REFERENSI}

Abdullah, M. A. (2014). Integrasi dan Interkoneksi Ilmu Pengetahuan”. In Paper dipresentasikan dalam acara Seminar Nasional Progam Pascasarjana UIN Sunan Kalijaga Yogyakarta. (pp. 15-16).

Achmad, N. (2001). Pluralitas Agama: Kerukunan dalam Keragaman. Kompas Media Nusantara.

Andrik, P. (2003). Komunikasi Multikultural. Universitas Muhammadiyah Surakarta: Muhammadiyah University Press.

As-Suyuthi, J. (2008). Asbab Al-Nuги I Sebab Turunnya Ayat Al-Qur'an. terj. Tim Abdul Hayyie. Jakarta: Gema Insani.

Dawam, A., \& Alafsana, S. (2003). "Emob" Sekolah: Menolak" Komersialisasi Pendidikan" Dan" Kanibalisme Intelektual”, Menuju Pendidikan Multikultural. Inspeal Ahimsakarya Press.

Ekosusilo, M., \& Kasihadi, R. B. (1993). Dasar-Dasar Pendidikan. Effhar Publishing.

Kottak, C. P. (1987). Anthropology: The Exploration of Human Diversity. Random House.

Maraghi, S. A. M. (2001). Tafsir Al-Maraghi. Dar al-Fikr.

Munawar, A., \& Husin, S. A. (2005). Fikih Hubungan Antar Agama. Ciputat: PT. Ciputat Press.

Mustofa, A. (1992). Terjemah Tafsir Al-Maraghi. Semarang: CV. Toha Putra.

Naim, N. (2011). Teologi Kerukunan: Mencari Titik Temu dalam Keragaman. Teras.

Nasional, U. (2008). Bahasa Indonesia. Jakarta: Pusat Bahasa Departemen Pendidikan Nasional.

Noor, R. M. (2010). KH Hasyim Asy'ari memodernisasi NU \& pendidikan Islam. Grafindo Khazanah Ilmu.

Rohman, M. (2016). Implementasi Nilai-Nilai Multikultural di MAN Yogyakarta III dan SMA Stella Duce 2 Yogyakarta.

Rohman, M. (2018). Konsep Pendidik. Berwawasan Multikultural dalam Lembaga Pendidikan.

Rohman, M., \& Lessy, Z. (2017). Practicing Multicultural Education through Religiously Affiliated Schools and Its Implications for Social Change. Jurnal Pendidikan Islam, 6(1). https://doi.org/10.14421/jpi.2017.61.1-24

Rohman, M., \& Mukhibat, M. (2017). Internalisasi Nilai-nilai Sosio-kultural Berbasis Etno-Religi di MAN Yogyakarta III. Edukasia: Jurnal Penelitian Pendidikan Islam, 12(1), 31-56. https://doi.org/10.21043/edukasia.v12i1.1771

Shihab, M. Q. (2006). Tafsir al-Mishbäh: Pesan. Kesan Dan Keserasian Al-Qur'an, 1. 
Sisdiknas. (2003). UU RI No. 20 Th. 2003 tentang Sistem Pendidikan Nasional. Jakarta: Sinar Grafika.

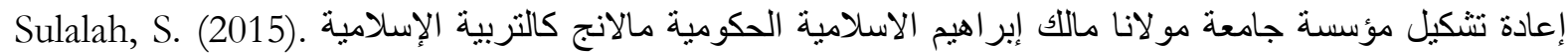

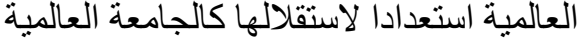

